\title{
Insight into the Epidemiology of Leptospirosis: A Review of Leptospira Isolations from "Unconventional" Hosts
}

\author{
Giovanni Cilia $\mathbb{D}$, Fabrizio Bertelloni *D, Sara Albini and Filippo Fratini \\ Department of Veterinary Sciences, University of Pisa, Viale delle Piagge 2, 56124 Pisa, Italy; \\ giovanni.cilia@vet.unipi.it (G.C.); sara.albini.p@gmail.com (S.A.); filippo.fratini@unipi.it (F.F.) \\ * Correspondence: fabrizio.bertelloni@unipi.it
}

check for

updates

Citation: Cilia, G.; Bertelloni, F.; Albini, S.; Fratini, F. Insight into the Epidemiology of Leptospirosis: A Review of Leptospira Isolations from “Unconventional" Hosts. Animals 2021, 11, 191. https://doi.org/ 10.3390/ani11010191

Received: 30 December 2020

Accepted: 12 January 2021

Published: 14 January 2021

Publisher's Note: MDPI stays neutral with regard to jurisdictional claims in published maps and institutional affiliations.

Copyright: (c) 2021 by the authors. Licensee MDPI, Basel, Switzerland. This article is an open access article distributed under the terms and conditions of the Creative Commons Attribution (CC BY) license (https:// creativecommons.org/licenses/by/ $4.0 /)$.
Simple Summary: The isolation of Leptospira is the most important test to assess infection in animal species. Several animals play a role as maintenance-host for specific serovars and in the last 30 years the incidence of leptospirosis has constantly increased in well-known reservoirs as well as in "unconventional" hosts. The emergence and the identification of Leptospira infection in such "unconventional" hosts could be related to several factors including problematic or inaccurate sampling modes during the Leptospira isolation, newly identified Leptospira strains, underestimated leptospirosis cases and climatic changes causing modifications of ecological niches. The aim of this review was to report the Leptospira isolations of the last 60 years from animals that could be considered "unconventional" hosts. Thus, the identification of "unconventional" hosts is crucial because they almost surely play an important role in the epidemiology of Leptospira infection.

Abstract: Leptospirosis is a re-emerging worldwide zoonotic disease. Even though the primary serological test for diagnosis and surveying is the microscopic agglutination test (MAT), isolation remains the gold-standard test to detect Leptospira infections. The leptospirosis transmission is linked to maintenance and accidental hosts. In the epidemiology of Leptospira some serovar are strictly related to specific maintenance hosts; however, in recent years, the bacterium was isolated from an even wider spectrum of species. The aim of this review is to report the isolation of Leptospira strains in animals which could be recognized as "unconventional" hosts, analyzing studies from 1960 to 2020 that highlighted the Leptospira isolation. This scientific literature aimed to provide evidence of infection in several animal species including of the Carnivora, Didelphimorphia, Rodentia, Cetacea, Cingulata, Afrosoricida, Chiroptera and Primate orders, as well as in Reptilia and Amphibia classes. In conclusion, the spreading of Leptospira is attention-worthy because the infection could occur in all the animal species ranging in a specific area. Further screening and isolations are needed to collect all necessary data to gain a complete understanding of leptospirosis epidemiology and its modifications.

Keywords: leptospirosis; Leptospira isolation; wildlife; zoonoses; host-pathogens interactions; public health

\section{Introduction}

Leptospirosis is a neglected and re-emerging zoonoses caused by a Gram-negative bacterium belonging to the Spirochaetaes phylum, Leptospiraceae family, Leptospira genus [1,2]. These microorganisms appear spiral-shaped, with a diameter of $0.1 \mu \mathrm{m}$ and a length of 6-20 $\mu \mathrm{m}$ and a pointed end that is typically folded into a characteristic hook shape [1] Leptospira is highly mobile and performs rotational movements around the central axis, translation, undulation, and flexion thanks to two periplasmic axial flagella located under the cell membrane [3]. Although Leptospira is a microaerophile, it develops well even in conditions of complete aerobiosis. The optimum temperature for its growth is between $28^{\circ} \mathrm{C}$ and $30^{\circ} \mathrm{C}$, although it also grows at $37^{\circ} \mathrm{C}$. The ideal $\mathrm{pH}$ range is between 7.2 and 7.4 [2].

Traditional classification divided the genus Leptospira in two species: L. interrogans, pathogenic strains, and L. biflexa, saprophytic strains. On the basis of antigenic agglutina- 
tion reactions and cross absorption, both species are divided into serovars. There are over 60 serovars belonging to the L. biflexa species, while there are more than 200 Leptospira interrogans [1,2]. Serovars are identified on the basis of their expression of surface epitopes in the mosaic of lipopolysaccharide antigens (LPS), where the specificity of the latter depends on the composition and orientation of sugars [4]. Traditionally, antigenic correlated serovars were grouped into serogroups, which are very relevant in the epidemiological field [5]. Currently, the Leptospira genus has undergone a re-classification on a genomic basis, which resulted in the identification of 13 species in addition to those already existing, reaching a total of 64 identified species [1]. This classification system may be more complicated than the previous one as, within the same species, pathogenic and non-pathogenic serovars are included, and specific serovars can be found within several species. For this reason, in several laboratories, the old classification is still used, mainly for convenience in the serological diagnosis [1]. Serovars, identified on a genomic basis, amount to more than 260 and are classified into pathogenic, intermediate, and saprophytic [6,7]. Pathogenic Leptospira are the causative agents of moderate to severe forms of the disease, while intermediate Leptospira generally cause less severe infections. On the other hand, saprophytic serovars, commonly present in the environment, are not considered pathogenic and can play a relevant role only when they undergo genetic recombination processes with pathogenic serovars [8,9].

The invasion of Leptospira into the body occurs through skin lesions (even of minimal entity), via the mucous membrane (conjunctiva and oral mucosa), and by contact with wet skin or by inhalation [2]. Infiltrated microorganisms invade the bloodstream, causing bacteremia that persists for about 5-7 days [10]. Once a critical number of bacteria has been reached in the blood, the first symptoms related to their trans-endothelial migration appear. The pathogenetic mechanism of Leptospira is not yet fully understood, and it is hypothesized that virulence factors, such as toxins, adhesins, and other surface proteins, are expressed [11]. Primary lesions affect the endothelium of small vessels and cause ischemic damage in various organs, including kidneys, liver, lungs, meninges, placenta, and muscles [10]. In certain cases, hemorrhages, jaundice due to the destruction of the hepatic architecture, and, more frequently, thrombocytopenia, may also occur [11]. Tissue damage, although severe, can undergo complete healing or its resolution can leave scar tissue, as is often observed in pig kidneys with the characteristic appearance of "white spots" [2].

The primary serological test used for diagnosis and for conducting surveys is the microscopic agglutination test (MAT), but isolation remains the gold-standard test to detect Leptospira infections. MAT is performed using a panel of live antigens, selected on the basis of the main serogroups circulating in the reference area, placed in contact with the serum under examination at an initial dilution of 1:100 and subsequent scaling dilutions. The concentration of the free Leptospira must be comparable to the negative control, consisting of the culture diluted 1:2 with physiological solution [2,12]. Subsequently, the positivity of the sample, given by the formation of the antigen-antibody complex that manifests itself through agglutination, is evaluated by observations under a microscope in a dark field [13]. It is possible to increase the sensitivity of the test by using locally isolated Leptospira instead of those belonging to the classic reference strains [12]. However, in order to diagnose Leptospira infections, isolation is the most specific method, even if it is often impractical and complicated, especially considering its time-consuming aspect [12]. Isolation is performed using a liquid medium, such as Ellinghausen-McCullough-Johnson-Harris (EMJH) or Fletcher media. Usually, to stimulate the Leptospira growth, albumin, bovine or rabbit serum, and Tween 80 or 40 is added [14]. To avoid the development of contaminating microorganisms, it is possible to use selective agents, such as 5-fluorouracil, nalidixic acid, fosfomycin, polymyxin, bacitracin, and neomycin [12]. The cultures, once prepared, are incubated at $29-30{ }^{\circ} \mathrm{C}$ for at least 12 weeks and preferably 26. Checks must be performed every 7-14 days, by observation under a darkfield microscope, to assess the state of bacterial growth [12]. Recently, a new alternative medium, called Hornsby-Alt-Nally (HAN), has been formulated which seems more effective in supporting the growth of Leptospira strains, at both 29 and $37^{\circ} \mathrm{C}$. The HAN medium seem to be optimal to per- 
form the primary isolation of fastidious pathogenic strains directly from infected host tissues, especially for strains belonging to L. borgpetersenii species [15]. Leptospirosis is a worldwide diffused disease, occurring in tropical, subtropical, and temperate zones $[4,16]$. The spread of the disease is favored by a large variety of both wild and domestic animals which can be natural reservoirs of Leptospira $[1,2,10,17-20]$. Several specimens are asymptomatic Leptospira renal carriers, contributing to maintain the infection in the environment by constantly shedding bacteria with urine and developing symptoms only after a long period of incubation [2,21]. The incidental contact with Leptospira infected urine by non-adapted animals, the so-called accidental hosts, could cause infections that evolve in the above-mentioned clinical diseases. For this reason, the epidemiology of leptospirosis in a particular ecosystem is related to the close relationship between specific Leptospira serovars and specific maintenance hosts $[17,21,22]$. For example, rodents are reservoirs of Icterohaemorrhagiae and Ballum serogroups [23,24], swine of Pomona and Tarassovi serogroups [25-29], horses of Bratislava serogroups [30,31], bovines and ovine of Sejroe serogroups [32,33]. In the last 30 years, the incidence of leptospirosis has constantly increased in well-known reservoirs as well as in never-before detected animal species [34-36]. The Leptospira incidence in these atypical hosts has become even higher, reaching several animal species from different classes and orders [37-39], including a wide spectrum of avian species (seagulls, doves, ibis, and owl) [40,41], reptiles [40,42] and fishes [43]. The emergence and the identification of Leptospira infection in such "unconventional" hosts could be related to: (i) problematic or inaccurate sampling methods to isolate Leptospira [12]; (ii) newly identified Leptospira strains [44]; (iii) underestimated leptospirosis cases, characterized by a downward trend [36]; (iv) climatic changes modifying ecological niches [16,45]; (v) presence of domestic animals raised in semi-extensive or extensive farms, promoting contact with wild species [16,46]; (vi) Leptospira strain antimicrobial resistances [47-49].

The epidemiology of Leptospira and leptospirosis is strictly related to the presence of susceptible hosts, both maintenance and accidental. Since isolation of viable bacteria represents the highest level of diagnosis and the best way to prove the relation between a pathogen and a host, the aim of this review was to report the Leptospira isolations of the last 60 years from animals that could be considered "unconventional" hosts. Animal species that are well recognized Leptospira hosts were not taken in consideration. Although in many cases, the data available in the literature are not sufficient to classify these "unconventional" hosts as incidental or maintenance, further knowledge of them could give new insights into the epidemiology of leptospirosis.

\section{Leptospira Isolation on "Unconventional" Host}

From 1960 to 2020, 34 papers were published about the isolation of Leptospira from species not recognized as leptospirosis reservoir. As showed in Figure 1, the published works increase constantly year after year, reporting Leptospira isolation from several animal species. Leptospira spp. isolated from animals belonging to the Carnivora order are the most numerous, followed by Didelphimorphia and Rodentia. However, isolation was obtained from Cetacea, Cingulata, Afrosoricida, Chiroptera and Primate, as well as in Reptilia and Amphibia classes. 


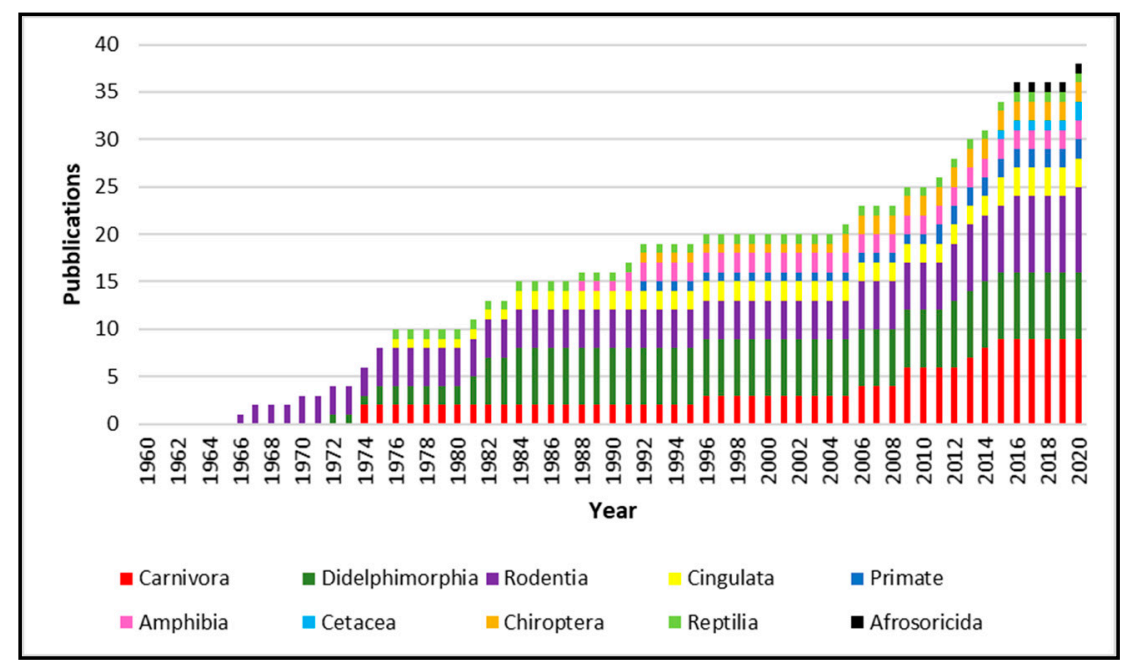

Figure 1. Number of f publications from 1960 to 2020 concerning Leptospira isolation from "unconventional" hosts. Different animal orders are represented with different colors.

The geographical distribution of Leptospira isolation (Figure 2) is more abundant in South America, especially in Brazil and Argentina, due to the high animal species variability present in this geographic area. Moreover, other isolations were performed in the North American West Coast, Italy, Netherlands, Japan, and Madagascar.

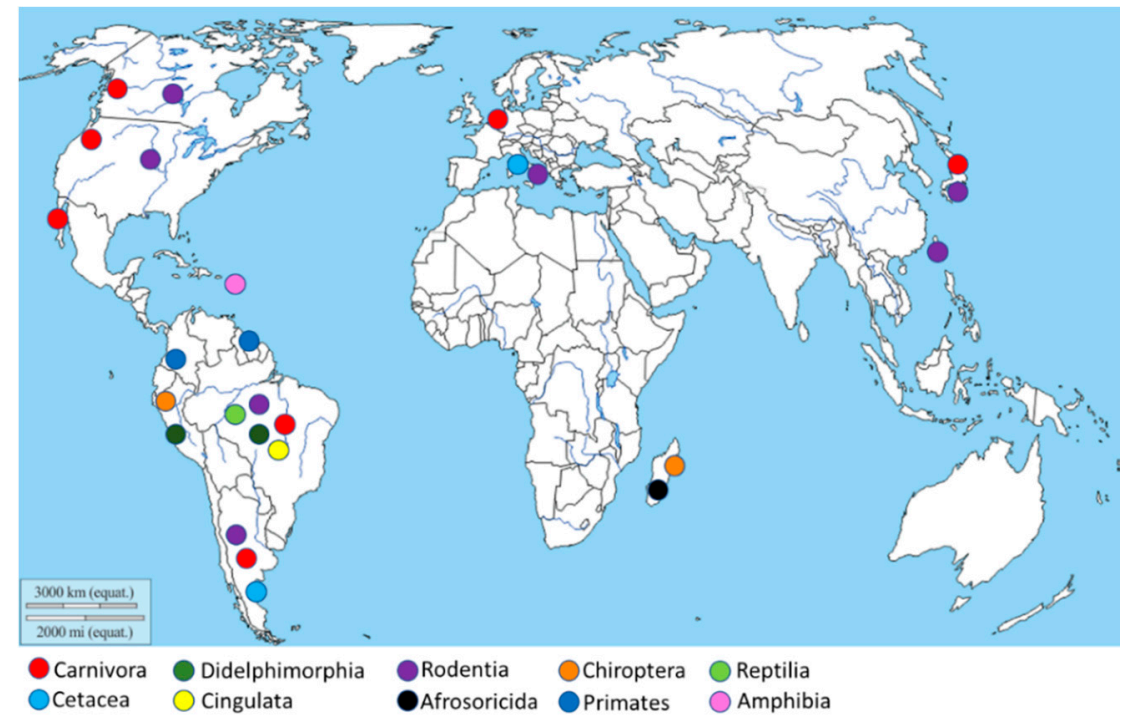

Figure 2. Geographical distribution of the Leptospira isolation. The map shows, through different colors, Leptospira isolation from different animal orders.

\subsection{Carnivora}

Among the Carnivora order, Leptospira was isolated from pinnipeds, racoons, and Gray fox (Table 1). Within Carnivora, pinnipeds were the most investigated animals, in which high number of isolations were reported. Within California sea lion (Zalophus californianus) and fur seal (Callorhinus ursinus) colonies Leptospira isolations were obtained from four leptospirosis outbreaks. From all of these, isolations from blood, kidney and urine, L. interrogans serogroup Pomona serovar Pomona were obtained [50-54]. The serovar Pomona is considered the most important cause of diseases in California sea lions, as widely reported from serological surveys and post-mortem lesions, reaching the $100 \%$ of colony population [50,51,55-58]. Moreover, serovar Pomona seems to be the reason of high incidence of abortion in this animal species, as suggested by the isolation obtained from its placenta [53]. 
Considering fur seal, on 29 specimens collected in Alaska, two isolations were obtained from a new-born puppy liver and another one from the urine of an adult male. Both isolations, as for California sea lions, belong to serovar Pomona [53], as demonstrated by MAT surveys on dead animals with hemorrhagic lesions [57]. Moreover, two groups from Phocidae family tested positive for Leptospira in the American West Coast, serovar Pomona was isolated from the kidney of a Northern elephant seal (Mirounga angustirostris) [59]. However, serological positivity, other than for serovar Pomona, was reported for Grippotyphosa and Bratislava, at high titers [60,61]. Additionally, from a harbor seal (Phoca vitulina) sampled in Netherlands, L. interrogans serogroup Icterohaemorrhagiae serovar Icterohaemorrhagiae was isolated [62]. The Leptospira infection was also detected in these animals through serological and molecular surveys of both free-ranging and captive specimens with even higher positivity, to Icterohaemorrhagiae, Grippotyphosa and Bratislava [60-66]. From two kidneys of racoons (Procyon lotor) L. interrogans serogroup Icterohaemorrhagiae and L. interrogans serogroup Hebdomadis serovar Hebdomadis were isolated in Japan [67]. This is the first isolation from this animal species, although anti-Leptospira antibodies were detected in racoon sera in North America [68-71]; furthermore, it was demonstrated that, in Canada, trappers contracted leptospirosis from contact with these carnivores [71]. Two isolations were obtained from the Canidae family from South America Gray fox (Lycalopex griseus) and Maikong (Cerdocyon thous). Serovar Icterohaemorrhagiae was isolated from one out of five south America Gray fox specimens collected in Argentina [72]. True foxes, belonging to Vulpes genus, are well recognized as Leptospira reservoir, in particular Red fox (Vulpes vulpes), [73-75], but no isolation was performed among them. Leptospira infection was detected only by serological studies that highlighted antibodies against serovars Icterohaemorrhagiae, Canicola, Hebdomadis, Hardjo and Grippotyphosa [76,77]. A Leptospira surveillance was never conducted on maikong (Cerdocyon thous) until 2015, when in Brazil a strain belonging to Pomona serogroup was isolated from these animals, while Bratislava, Shermani and Whitcombi was also detected by MAT [78].

\subsection{Cetacea}

Among species belonging to the Cetacea order, only two isolations have occurred so far (Table 1). One study describes the characterization of Leptospira strain Manara, as collected from a Southern right whale (Eubalaena australis) stranded in Patagonia [79]. Moreover, this strain turned out to be halophilic, surviving in a salt environment, at different concentrations, for a few days. The other isolation of serovar Pomona was obtained from the kidney of a common bottlenose dolphin (Tursiops truncates) collected in Sardinia (Italy) [80]. These are the only isolations from whale and dolphin species, among several investigated species around the world [40,81-85].

\subsection{Didelphimorphia}

Several opossum species are widely diffused in all South American countries. A very wide diversity of Leptospira species have been isolated from kidneys and urines of opossums (Table 1). From the common opossum (Didelphis marsupialis) sampled in Peru and Brazil, leptospires belonging to serovar Grippotyphosa, Ballum, Brasiliensis, Szwajzak, Icterohaemorrhagiae, Autumnalis, Tingomaria, Georgia, Huallaga, Rupa rupa were isolated [86-90]. Additionally, in Brazil, L. borgpetersenii serovar Castellonis and two strains belonging to serogroup Panama and Pomona, respectively, were isolated from white-eared opossum (Didelphis albiventris) [91,92]. Finally, among the Gray foureyed opossum (Philander opossum) in both the Brazilian and Peruvian area, another large variety of Leptospira strains were detected $[87,89,90,92]$, as shown in Table 1; in particular, serovars Ballum, Grippotyphosa, Tingomaria, Georgia, and Icterohaemorrhagiae were isolated. Marsupials have been reported to harbor serovars such as L. kirschneri serovar Grippotyphosa [10] and L. interrogans serovar Canicola [93]. However, all investigated opossum species presented low antibody titers in MAT investigation, suggesting that opossum could be only moderately susceptible to infection [2]. Moreover, opossums 
experimentally intraperitoneally inoculated with serovar Grippotyphosa did not show clinical signs, although lesions attributed to leptospirosis were observed in liver and kidney tissues [94].

\subsection{Cingulata}

Very few studies were conducted on armadillo's species and only in Brazil. As reported in Table 1, serogroup Autumnalis, Cynopteri, Hebdomadis and Pomona were isolated from kidneys of nine-banded armadillo (Dasypus novemcinctus) [88,95]. Also, a strain belonging to serogroup Pomona was isolated from the urine of a six-banded armadillo (Euphractus sexcinctus) [78]. Other serological investigations on armadillo specimens indicate the presence of antibodies to serogroups Autumnalis, Cynopteri, and Pomona at titer reaching 1:1600 [96,97], suggesting that this animal could be susceptible to leptospirosis as an incidental host.

\subsection{Rodentia}

Detailed and recent reviews of literature about leptospirosis in rodent species have been widely treated elsewhere hence they will not be discussed in this article. Indeed, rodents are considered to be one of the most important reservoirs of Leptospira [2]. Infections have already been demonstrated in different urban, wild, and imported rodent species, such as Apodemus, Delomys, Mus, Necromys, Oryzomys, Rattus, Thaptomys, Trinomys and Myocastor coypus $[98,99]$. However, few data are present in the literature about the role of squirrels and the largest rodents, capybara, and porcupine, in the leptospirosis epidemiology. Among squirrels (Table 1), Ballum and Grippotyphosa serovars were isolated from fox squirrels (Sciurus niger) [100,101], while Grippotyphosa serogroup from Southern flying squirrel (Glaucomys volans) [102], serogroup Javanica from Pallas's squirrel (Callosciurus flavimanus) [103] and serovar Icterohaemorrhagiae and Canicola from redbellied tree squirrel (Callosciurus erythraeus) [104]. All of these studies highlighted the role of squirrels as renal carriers, although their role in epidemiology remains unknown. The largest rodents in the world, capybara (Hydrochoerus hydrochaeris), seem to be incidental hosts of Leptospira, as demonstrated by the isolation of serovar Icterohaemorrhagiae and serovar Bananal in Brazil [105,106]. Moreover, other findings suggest that incidental contact with the pathogens indicates asymptomatic infection due to L. santarosai identified through molecular amplification [106], and by the experimental infection with a strain belonging to serovar Pomona [107]. Among porcupines, isolations of serovar Pomona were performed only from crested porcupine (Hystrix cristata) in Italy, and from North American porcupine (Erethizon dorsatum) in Canada $[108,109]$. The role of this animal species remains unknown because it could be an incidental host or a reservoir of Leptospira. However, crested porcupine specimens resulted positive for serogroup Icterohaemorrhagiae (also a titer $\leq 1: 1600$ ), and for Australis and Pomona (at low titers) during a serological survey [110]. Also, anti-Leptospira antibodies to serovars Javanica, Hurstbridge, Ballum, Celledoni and Hardjoprajitno were detected [111]. Finally, molecular analysis of the urine of orange-spined hairy dwarf porcupine (Sphiggurus villosus) reported a renal Leptospira infection, despite the MAT negative results [112], suggesting a role as reservoir.

\subsection{Afrosoricida}

The only investigation on the Afrosoricida order highlighted the isolation of L. mayottensis from a tailless tenrec (Tenrec ecaudatus) (Table 1) sampled in Mayotte Islands [113]. This valuable piece of information was the nearly perfect identity scored form the tenrec strains and they obtained from ill human patients. The L. mayottensis typically circulates in the Mayotte islands, reaching not only humans but also domestic animals $[7,50,114]$. Probably, tenrec was an incidental host, but a role as reservoir is not to be excluded 
Table 1. Serogroup and Serovar of Leptospira isolated from "unconventional" host specimens, of which are reported Class, Order, Family, Species and Country of collection.

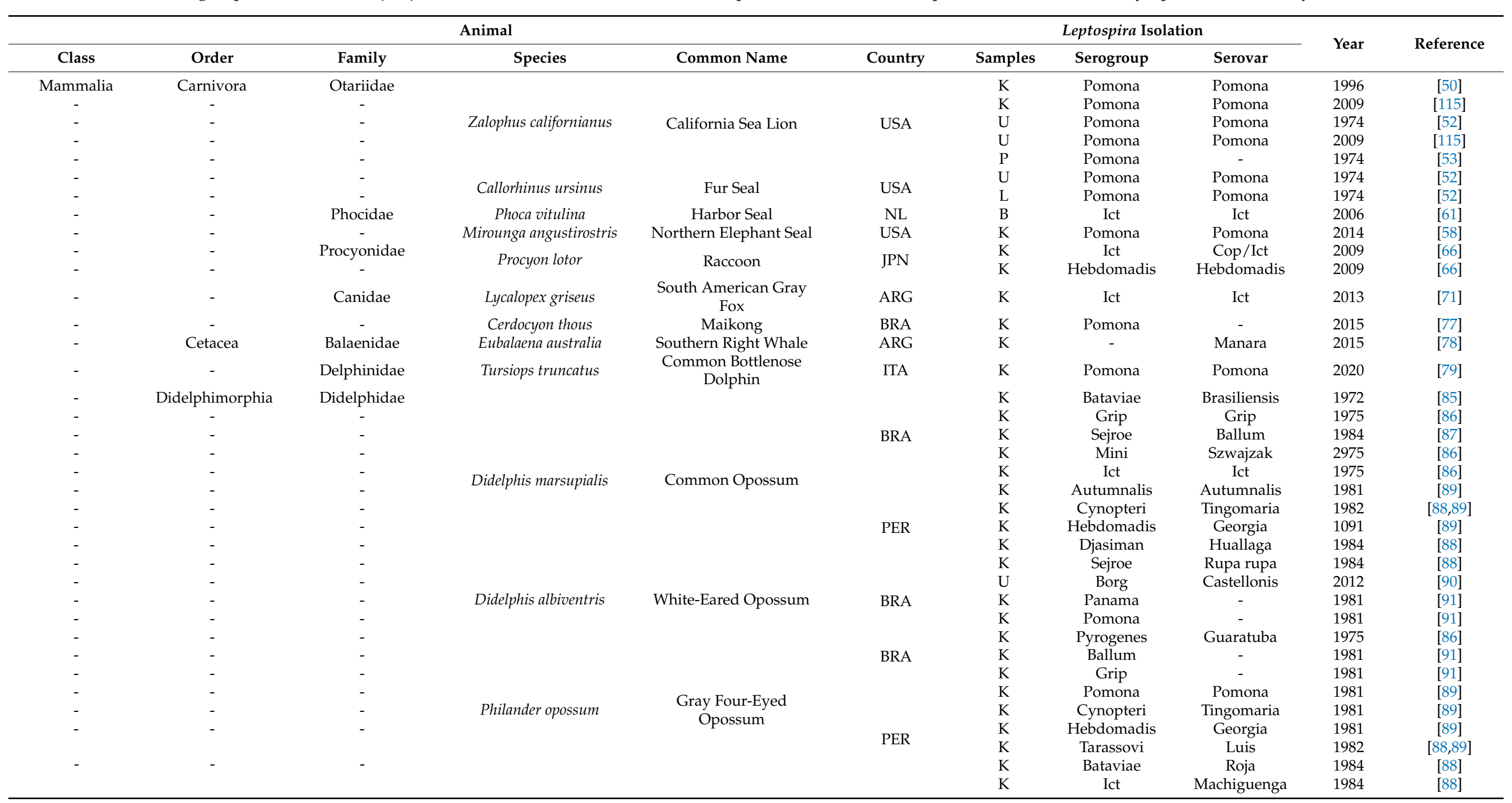


Table 1. Cont.

\begin{tabular}{|c|c|c|c|c|c|c|c|c|c|c|}
\hline \multicolumn{6}{|c|}{ Animal } & \multicolumn{3}{|c|}{ Leptospira Isolation } & \multirow{2}{*}{ Year } & \multirow{2}{*}{ Reference } \\
\hline Class & Order & Family & Species & Common Name & Country & Samples & Serogroup & Serovar & & \\
\hline - & - & - & - & - & - & - & - & - & - & - \\
\hline - & Cingulata & Dasypodidae & \multirow{3}{*}{ Dasypus novemcinctus } & & & $\mathrm{K}$ & Autumnalis & - & 1984 & [87] \\
\hline - & - & - & & \multirow[t]{2}{*}{ Nine-Banded Armadillo } & \multirow[t]{2}{*}{ BRA } & $\mathrm{K}$ & Hebdomadis & - & 1975 & {$[87,94]$} \\
\hline - & - & - & & & & $\mathrm{K}$ & Pomona & - & 1976 & [94] \\
\hline - & - & - & Euphractus sexcinctus & Six-Banded Armadillo & BRA & $\mathrm{U}$ & Pomona & - & 2015 & [77] \\
\hline - & Rodentia & Caviidae & \multirow{2}{*}{ Hydrochoerus hydrochaeris } & \multirow{2}{*}{ Capybara } & \multirow[b]{2}{*}{ BRA } & $\mathrm{K}$ & Ict & Ict/Cop & 2012 & [104] \\
\hline- & - & - & & & & $\mathrm{K}$ & Grip & Bananal & 2016 & [105] \\
\hline- & - & - & Callosciurus erythraeus & Red-Bellied Tree Squirrel & ARG & $\mathrm{K}$ & Canicola & Canicola & 2013 & [103] \\
\hline- & - & - & Glaucomys volans & Southern Flying Squirrel & JPN & $\mathrm{K}$ & Grip & - & 2006 & {$[101]$} \\
\hline - & - & - & Callosciurus flavimanus & Pallas's Squirrel & TWN & $\mathrm{K}$ & Javanica & - & 2007 & [102] \\
\hline - & - & - & \multirow{2}{*}{ Sciurus niger } & \multirow{2}{*}{ Fox squirrel } & \multirow[b]{2}{*}{ USA } & \multirow[b]{2}{*}{ K } & Ballum & - & 1975 & [99] \\
\hline - & - & - & & & & & Grip & - & 1967 & {$[99,100]$} \\
\hline - & - & Erethizontidae & \multirow{2}{*}{ Erethizon dorsatum } & \multirow{2}{*}{$\begin{array}{l}\text { North American } \\
\text { Porcupine }\end{array}$} & \multirow{2}{*}{ CAN } & $\mathrm{B}$ & Pomona & Pomona & 1966 & [108] \\
\hline - & - & - & & & & $\mathrm{U}$ & Pomona & Pomona & 1966 & [108] \\
\hline - & - & Hystricidae & Hystrix crsitata & Crested Porcupine & ITA & $\mathrm{K}$ & Pomona & Pomona & 2020 & [107] \\
\hline- & Afrosoricida & Tenrecidae & \multirow{2}{*}{$\begin{array}{c}\text { Tenrec ecaudatus } \\
\text { Pteropus seychellensis } \\
\text { comorensis }\end{array}$} & Tailless Tenrec & MD & $\mathrm{K}$ & Mayottensis & - & 2016 & [112] \\
\hline- & Chiroptera & Pteropodidae & & Seychelles Flying Fox & $\mathrm{MD}$ & K & Grip & - & 2016 & [112] \\
\hline - & - & - & Mimon crenulatum & Striped Hairy-Nosed Bat & PER & $\mathrm{K}$ & Grip & Grip & 2005 & {$[115]$} \\
\hline - & - & - & Promops nasutus; & Brown Mastiff Bat & PER & $\mathrm{K}$ & Grip & Grip & 2005 & [115] \\
\hline - & Primates & Lemuridae & Lemur catta & Ring-tailed Lemur & PT & $\mathrm{B}$ & Ict & Cop & 2019 & [116] \\
\hline - & - & Cebidae & Callithrix jacchius & Common Marmoset & $\mathrm{PT}$ & B & Ict & Cop & 2019 & [116] \\
\hline- & - & - & Saimiri sciureus & Squirrel Monkey & FG & B & Ict & Cop & 1992 & [117] \\
\hline- & - & - & Cebus capuchinus & $\begin{array}{l}\text { White-Faced Capuchin } \\
\text { Monkeys }\end{array}$ & $\mathrm{COL}$ & $\mathrm{B}$ & Ict & Cop/Ict & 2011 & [118] \\
\hline- & - & - & Cebus apella & $\begin{array}{l}\text { Tufted Capuchin } \\
\text { Monkeys }\end{array}$ & PT & B & Ict & Cop/Ict & 2011 & {$[116,118]$} \\
\hline Reptilia & Squamata & Viperidae & Bothrops pradoi & $\begin{array}{c}\text { Prado's Lancehead } \\
\text { Snake }\end{array}$ & BRA & K & Andaman & Andamana & 1976 & [119] \\
\hline- & - & Colubridae & Heterodon platghrinus & Hognosed Snake & USA & K & Ballum & - & 1961 & [120] \\
\hline Amphibia & Anura & Bufonidae & & & & $\mathrm{K}$ & Australis & Bim & 1991 & [121] \\
\hline- & - & - & & & & $\mathrm{K}$ & Australis & Bajan & 1991 & {$[121]$} \\
\hline - & - & - & Bufo marinus & Marine Toad & BRB & B & Autumnalis & Bim & 1988 & {$[122]$} \\
\hline - & - & - & & & & $\mathrm{U}$ & Autumnalis & Bim & 1988 & [122] \\
\hline - & - & Eleutherodactylidae & & & & $\mathrm{K}$ & Autumnalis & Bim & 1991 & [121] \\
\hline - & - & - & Eleutherodactylus & Whistling Frog & $\mathrm{BRB}$ & $\mathrm{K}$ & Autumnalis & Bim & 1991 & [121] \\
\hline - & - & - & johnstonei & & & $\mathrm{K}$ & Australis & Bajan & 1991 & {$[121]$} \\
\hline
\end{tabular}

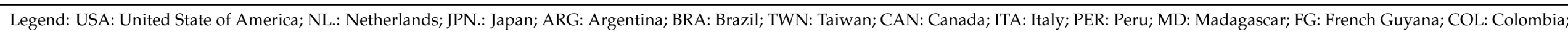
PT: Portugal; BRB: Barbados; K: Kidney; U: Urine; P: Placenta; L: Liver; B: Blood; Ict: Icterohaemorrhagiae; Cop: Copenhageni; Grip: Grippotyphosa; Borg: Borgpetersen. 


\subsection{Chiroptera}

Bats are widely researched about their role in the epidemiology of leptospirosis [123]. However, only a few isolations were performed, highlighting infection by L. kirschneri serogroup Grippotyphosa and L. interrogans serogroup Icterohaemorrhagiae (Table 1). Strains belonging to serogroup Grippotyphosa were isolated in Peru from the kidney of a striped hairy-nosed bat (Mimon crenulatum) and a brown mastiff bat (Promops nasutus) [98] and in Madagascar from Seychelles flying fox (Pteropus seychellensis comorensis) [97]. Also, serovar Icterohaemorragiae was isolated from the greater spear-nosed bat (Phyllostomus hastatus) in Peru [98]. The role of bats in the Leptospira spreading remains unknown because all of these isolations seem not to be related to serogroups/serovars detected by MAT [124-129], although high prevalence were reported using molecular detection [115,130-134]. Furthermore, increasing the uncertainty of the role of bats as reservoir, several isolation investigations scored negative $[115,124]$, leaving the issue open.

\subsection{Primates}

Within Leptospira epidemiology, non-human primates could provide important data due to their close lineage with human beings. Although some investigations were carried out on animals kept in captivity, other studies performed on free-ranging monkeys indicated an interesting prevalence of Leptospira infection [135]. The infections occurring in several primate species were mainly caused by strain of L. interrogans serogroup Icterohaemorrhagiae and L. borgpetersenii serogroup Ballum, serologically detected [136-144]. The serological results were confirmed with Leptospira isolation in only two cases (Table 1). Among prosimian, blood samples collected from a specimen of ring-tailed lemur (Lemur catta) kept in a Portuguese zoological park scored positive to Leptospira infection and serovar Copenhageni was isolated [116]. Moreover, serogroup Icterohaemorrhagiae have been isolated from the blood of captive specimens of squirrel monkey (Saimiri sciures) in French Guyana and of white-faced capuchin monkey (Cebus capuchinus and Cebus apella) in Colombia and in Portugal and of a common marmoset (Callithrix jacchus) kept in a Portuguese zoological park [116-118]. The isolation from squirrel monkey was performed after an outbreak in a colony bred in captivity, where some animals showed jaundice and hemorrhagic syndrome, death, and abortion [117]. All symptoms were referable to leptospirosis and were confirmed by serology and isolation. In the case of white-faced capuchin monkey, too, the isolation was performed after the incoming of leptospirosis symptoms in a colony kept in a recovery center, in which specimens had died despite antibiotic treatments [118].

\subsection{Reptilia}

Among Leptospira hosts, reptiles seem to be relevant as well. In these animals, leptospirosis could occur after the ingestion of rodents, typical maintenance-Leptospira-host, or due to contact with humid and contaminated environment $[42,145]$. Moreover, implication and pathogenesis remain unclear in these animals. Presently, only two isolations were reported in two snake species (Table 1). Serovar Andamana strains were isolated in Brazil from a kidney of a Prado's lancehead snake (Bothrops pradoi) [121]. Furthermore, a strain belonging to serogroup Ballum was found in hognosed snake (Heterodon platghrinus) [120]. Serogroup Ballum was previously detected in one more snake species [119]. In several snake species, different Leptospira serogroups were detected using serological assay [146,147], including Andamana and Ballum [119]. This suggests that snakes are incidental hosts, susceptible to environmental Leptospira contaminations due to different landscapes and living fauna.

\subsection{Amphibia}

As for reptiles, little information is available about leptospirosis in toads and frogs. In the Barbados islands, the marine toad (Bufo maninus) and the whistling frog (Eleutherodactylus johnstonei) were investigated, with very similar results (Table 1). L. interrogans serogroup Autumnalis serovar Bim were isolated from three out of four marine toads and 
two out of three whistling frogs [121,122]. The other specimens were both infected by L. interrogans serogroup Australis serovar Bajan [121,122]. Moreover, serological data for toads are available, showing Australis, Autumnalis and Panama infection [122], while no data are present for frogs. No piece of data clarifies if amphibians develop severe and lethal infection, but as well as reptiles, the infections are strictly related to Leptospira infection in a specific geographical area. The infection could penetrate in amphibians through water, as these animals can absorb water through their skin, store it in their urinary bladder and reabsorb it during dehydration stress. This mechanism seems to be the most probable cause of leptospirosis in toads and frogs [42].

\section{Conclusions}

Leptospirosis is probably the most prevalent, underestimated, and re-emerging zoonotic disease; animals, both wild and domestic, represent one of its most important transmission sources. This review highlighted several worldwide Leptospira isolations from a wide range of a "new" potential reservoir, ranging from rodent, opossum and carnivora species to bats, armadillos, cetaceans, reptiles, and amphibians. The amount of isolation has constantly increased during the last 50 years, suggesting that all free-ranging animals could be an incidental Leptospira host, including marine mammals. Probably, Leptospira infection is endemic in many countries with no surveillance or diagnostic facilities, especially for animals, such as in several African countries where leptospirosis has rarely or never been reported. These findings are undoubtedly of high importance for human public health, due to the risk of human infection through interaction with the reservoir or incidental hosts or contact with biological materials, including blood, urine, tissue, and excretions. Such risks could affect not only already confirmed worker categories (i.e., veterinarians, trappers, abattoir workers, farm workers, hunters, animal shelter workers and scientists and technologists handling animals in laboratories or during field work) but also marine mammal workers, fishmen, researchers, wildlife rehabilitators, trainers, and zoological park workers.

A better knowledge of the epidemiology of this infectious disease is essential to facilitate the creation of efficient prevention and control programs using a One Health approach. Constant monitoring is needed to control the evolution of the dynamics of leptospirosis epidemiology, mainly focused on new animal species that could contribute to its spreading, in order to better clarify their role as a reservoir or incidental hosts.

Author Contributions: Conceptualization, G.C., F.B. and F.F.; data curation, G.C., F.B., S.A. and F.F.; writing—original draft preparation, G.C. and F.B.; writing—review and editing, G.C., F.B., S.A. and F.F.; supervision, F.F. All authors have read and agreed to the published version of the manuscript.

Funding: This research received no external funding

Conflicts of Interest: The authors declare no conflict of interest.

\section{References}

1. Levett, P.N. Leptospirosis. Clin. Microbiol. Rev. 2001, 14, 296-326. [CrossRef]

2. Adler, B.; de la Peña Moctezuma, A. Leptospira and leptospirosis. Vet. Microbiol. 2010, 140, 287-296. [CrossRef]

3. Goldstein, S.F.; Charon, N.W. Motility of the spirochete leptospira. Cell Motil. Cytoskelet. 1988, 9, 101-110. [CrossRef]

4. Adler, B. Leptospira and Leptospirosis. In Current Topics in Microbiology and Immunology; Springer: Berlin, Germany, 2015; ISBN 978-3-662-45059-8.

5. Kmety, E.; Dikken, H. Classification of the Species Leptospira Interrogans and History of its Serovars; University Press Groningen: Groningen, The Netherlands, 1993.

6. Guglielmini, J.; Bourhy, P.; Schiettekatte, O.; Zinini, F.; Brisse, S.; Picardeau, M. Genus-wide Leptospira core genome multilocus sequence typing for strain taxonomy and global surveillance. PLoS Negl. Trop. Dis. 2019, 13, e0007374. [CrossRef]

7. Vincent, A.T.; Schiettekatte, O.; Goarant, C.; Neela, V.K.; Bernet, E.; Thibeaux, R.; Ismail, N.; Mohd Khalid, M.K.N.; Amran, F.; Masuzawa, T.; et al. Revisiting the taxonomy and evolution of pathogenicity of the genus Leptospira through the prism of genomics. PLoS Negl. Trop. Dis. 2019, 13, e0007270. [CrossRef] [PubMed] 
8. Balamurugan, V.; Gangadhar, N.L.; Mohandoss, N.; Thirumalesh, S.R.A.; Dhar, M.; Shome, R.; Krishnamoorthy, P.; Prabhudas, K.; Rahman, H. Characterization of leptospira isolates from animals and humans: Phylogenetic analysis identifies the prevalence of intermediate species in India. Springerplus 2013, 2, 362. [CrossRef]

9. Barragan, V.; Chiriboga, J.; Miller, E.; Olivas, S.; Birdsell, D.; Hepp, C.; Hornstra, H.; Schupp, J.M.; Morales, M.; Gonzalez, M.; et al. High Leptospira Diversity in Animals and Humans Complicates the Search for Common Reservoirs of Human Disease in Rural Ecuador. PLoS Negl. Trop. Dis. 2016, 10, e0004990. [CrossRef] [PubMed]

10. Bharti, A.R.; Nally, J.E.; Ricaldi, J.N.; Matthias, M.A.; Diaz, M.M.; Lovett, M.A.; Levett, P.N.; Gilman, R.H.; Willig, M.R.; Gotuzzo, E.; et al. Leptospirosis: A zoonotic disease of global importance. Lancet Infect. Dis. 2003, 3, 757-771. [CrossRef]

11. Levett, P.N.; Haake, D.A. Leptospira Species (Leptospirosis). In Principles and Practice of Infectious Diseases; Churchill Livingstone Elsevier: Philadelphia, PA, USA, 2010; pp. 3059-3065.

12. Leptospirosis. In OIE Terrestrial Manual 2018; World Organization for Animal Health: Paris, France, 2018 ; pp. 503-516.

13. Musso, D.; La Scola, B. Laboratory diagnosis of leptospirosis: A challenge. J. Microbiol. Immunol. Infect. 2013, 46, 245-252. [CrossRef]

14. Arent, Z.J.; Ellis, W.A. Leptospirosis. In Diseases of Swine; Zimmerman, J.J., Karriker, L.A., Ramirez, A., Schwartz, K.J., Stevenson, G.W., Zhang, J., Eds.; Wiley \& Sons: Hoboken, NJ, USA, 2019; pp. 854-862. ISBN 9781119350927.

15. Hornsby, R.L.; Alt, D.P.; Nally, J.E. Isolation and propagation of leptospires at $37^{\circ} \mathrm{C}$ directly from the mammalian host. Sci. Rep. 2020, 10, 9620. [CrossRef]

16. Bertelloni, F.; Cilia, G.; Turchi, B.; Pinzauti, P.; Cerri, D.; Fratini, F. Epidemiology of leptospirosis in North-Central Italy: Fifteen years of serological data (2002-2016). Comp. Immunol. Microbiol. Infect. Dis. 2019, 65, 14-22. [CrossRef] [PubMed]

17. Fratini, F.; Bertelloni, F.; Cilia, G. Leptospira Infection in Wild Animals; Nova Science Publisher: Hauppauge, NY, USA, 2020; ISBN 978-1-53618-222-4.

18. Cilia, G.; Bertelloni, F.; Mignone, W.; Spina, S.; Berio, E.; Razzuoli, E.; Vencia, W.; Franco, V.; Cecchi, F.; Bogi, S.; et al. Molecular detection of Leptospira spp. in wild boar (Sus scrofa) hunted in Liguria region (Italy). Comp. Immunol. Microbiol. Infect. Dis. 2020, 68, 101410. [CrossRef] [PubMed]

19. Ebani, V.V.; Bertelloni, F.; Pinzauti, P.; Cerri, D. Seroprevalence of Leptospira spp. and Borrelia burgdorferi sensu lato in Italian horses. Ann. Agric. Environ. Med. 2012, 19, 237-240. [PubMed]

20. Cilia, G.; Bertelloni, F.; Piredda, I.; Ponti, M.N.; Turchi, B.; Cantinle, C.; Parisi, F.; Pinzauti, P.; Armani, A.; Palmas, B.; et al. Presence of pathogenic Leptospira spp. in the reproductive system and fetuses of wild boars (Sus scrofa) in Italy. PLoS Negl. Trop. Dis. 2020, 14, e0008982. [CrossRef] [PubMed]

21. Ellis, W.A. Animal Leptospirosis. In Leptospira and Leptospirosis; Springer: Berlin, Germany, 2015; pp. 99-137.

22. Cilia, G.; Bertelloni, F.; Angelini, M.; Cerri, D.; Fratini, F. Leptospira Survey in Wild Boar (Sus scrofa) Hunted in Tuscany, Central Italy. Pathogens 2020, 9, 377. [CrossRef]

23. Blasdell, K.R.; Morand, S.; Perera, D.; Firth, C. Association of rodent-borne Leptospira spp. with urban environments in Malaysian Borneo. PLoS Negl. Trop. Dis. 2019, 13, e0007141. [CrossRef]

24. Mori, M.; Bourhy, P.; Le Guyader, M.; van Esbroeck, M.; Djelouadji, Z.; Septfons, A.; Kodjo, A.; Picardeau, M. Pet rodents as possible risk for leptospirosis, Belgium and France, 2009 to 2016. Eurosurveillance 2017, 22. [CrossRef]

25. Bertelloni, F.; Mazzei, M.; Cilia, G.; Forzan, M.; Felicioli, A.; Sagona, S.; Bandecchi, P.; Turchi, B.; Cerri, D.; Fratini, F. Serological Survey on Bacterial and Viral Pathogens in Wild Boars Hunted in Tuscany. Ecohealth 2020, 17, 85-93. [CrossRef]

26. Vale-Goncalves, H.M.; Cabral, J.A.; Faria, M.C.; Nunes-Pereira, M.; Faria, A.S.; Veloso, O.; Vieira, M.L.; Paiva-Cardoso, M.N. Prevalence of Leptospira antibodies in wild boars (Sus scrofa) from Northern Portugal: Risk factor analysis. Epidemiol. Infect. 2015, 143, 2126-2130. [CrossRef]

27. Vengust, G.; Lindtner-Knific, R.; Zele, D.; Bidovec, A. Leptospira antibodies in wild boars (Sus scrofa) in Slovenia. Eur. J. Wildl. Res. 2008, 54, 749-752. [CrossRef]

28. Boqvist, S.; Bergström, K.; Magnusson, U. Prevalence of antibody to six Leptospira Servovars in Swedish wild boars. J. Wildl. Dis. 2012, 48, 492-496. [CrossRef] [PubMed]

29. Cilia, G.; Bertelloni, F. Leptospira Infection in Wild Boar (Sus scrofa). In Leptospira Infection in Wild Animals; Fratini, F., Bertelloni, F., Cilia, G., Eds.; Nova Science Publisher: Hauppauge, NY, USA, 2020; pp. 53-77.

30. Arent, Z.; Frizzell, C.; Gilmore, C.; Allen, A.; Ellis, W.A. Leptospira interrogans serovars Bratislava and Muenchen animal infections: Implications for epidemiology and control. Vet. Microbiol. 2016, 190, 19-26. [CrossRef] [PubMed]

31. Rocha, T.; Ellis, W.A.; Montgomery, J.; Gilmore, C.; Regalla, J.; Brem, S. Microbiological and serological study of leptospirosis in horses at slaughter: First isolations. Res. Vet. Sci. 2004, 76, 199-202. [CrossRef] [PubMed]

32. Farina, R.; Cerri, D.; Renzoni, G.; Andreani, E.; Mani, P.; Ebani, V.; Pedrini, A.; Nuvoloni, R. Leptospira interrogans in the genital tract of sheep. Research on ewes and rams experimentally infected with serovar hardjo (hardjobovis). New Microbiol. 1996, 19, 235-242. [PubMed]

33. Cerri, D.; Ebani, V.V.; Fratini, F.; Pinzauti, P.; Andreani, E. Epidemiology of leptospirosis: Observations on serological data obtained by a "diagnostic laboratory for leptospirosis" from 1995 to 2001. New Microbiol. 2003, 26, 383-389. [PubMed]

34. Chikeka, I.; Dumler, J.S. Neglected bacterial zoonoses. Clin. Microbiol. Infect. 2015, 21, 404-415. [CrossRef] [PubMed]

35. Vijayachari, P.; Sugunan, A.P.; Shriram, A.N. Leptospirosis: An emerging global public health problem. J. Biosci. 2008, 33, 557-569. [CrossRef] 
36. Hartskeerl, R.; Collares-Pereira, M.; Ellis, W.A. Emergence, control and re-emerging leptospirosis: Dynamics of infection in the changing world. Clin. Microbiol. Infect. 2011, 17, 494-501. [CrossRef]

37. Xu, Y.; Zhu, Y.; Wang, Y.; Chang, Y.F.; Zhang, Y.; Jiang, X.; Zhuang, X.; Zhu, Y.; Zhang, J.; Zeng, L.; et al. Whole genome sequencing revealed host adaptation-focused genomic plasticity of pathogenic Leptospira. Sci. Rep. 2016, 6, 1-11. [CrossRef]

38. Cinco, M. New insights into the pathogenicity of leptospires: Evasion of host defences. New Microbiol. $2010,33,283-292$.

39. Espinosa-Martínez, D.V.; Sánchez-Montes, D.S.; León-Paniagua, L.; Ríos-Muñoz, C.A.; Berzunza-Cruz, M.; Becker, I. New Wildlife Hosts of Leptospira interrogans in Campeche, Mexico. Rev. Inst. Med. Trop. Sao Paulo 2015, 57, 181-183. [CrossRef] [PubMed]

40. Bogomolni, A.L.; Gast, R.J.; Ellis, J.C.; Dennett, M.; Pugliares, K.R.; Lentell, B.J.; Moore, M.J. Victims or vectors: A survey of marine vertebrate zoonoses from coastal waters of the Northwest Atlantic. Dis. Aquat. Organ. 2008, 81, 13-38. [CrossRef] [PubMed]

41. Jobbins, S.E.; Alexander, K.A. Evidence of Leptospira sp. infection among a diversity of African wildlife species: Beyond the usual suspects. Trans. R. Soc. Trop. Med. Hyg. 2015, 109, 349-351. [CrossRef] [PubMed]

42. Ebani, V.V. Leptospira Infection in Amphibians and Reptiles. In Leptospira Infection in Wild Animals; Fratini, F., Bertelloni, F., Cilia, G., Eds.; Nova Science Publisher: Hauppauge, NY, USA, 2020; pp. 205-218.

43. Thibeaux, R.; Girault, D.; Bierque, E.; Soupé-Gilbert, M.-E.; Rettinger, A.; Douyère, A.; Meyer, M.; Iraola, G.; Picardeau, M.; Goarant, C. Biodiversity of Environmental Leptospira: Improving Identification and Revisiting the Diagnosis. Front. Microbiol. 2018, 9, 816. [CrossRef] [PubMed]

44. Cilia, G.; Fratini, F.; della Buona, E.; Bertelloni, F. Preliminary Evaluation of In Vitro Bacteriostatic and Bactericidal Effect of Salt on Leptospira spp. Vet. Sci. 2020, 7, 154. [CrossRef] [PubMed]

45. Dupouey, J.; Faucher, B.; Edouard, S.; Richet, H.; Kodjo, A.; Drancourt, M.; Davoust, B. Human leptospirosis: An emerging risk in Europe? Comp. Immunol. Microbiol. Infect. Dis. 2014, 37, 77-83. [CrossRef]

46. Bertelloni, F.; Cilia, G.; Fratini, F. Bacteriostatic and Bactericidal Effect of Tigecycline on Leptospira spp. Antibiotics 2020, 9, 467. [CrossRef]

47. Liegeon, G.; Delory, T.; Picardeau, M. Antibiotic susceptibilities of livestock isolates of leptospira. Int. J. Antimicrob. Agents 2018, 51, 693-699. [CrossRef]

48. Ressner, R.A.; Griffith, M.E.; Beckius, M.L.; Pimentel, G.; Miller, R.S.; Mende, K.; Fraser, S.L.; Galloway, R.L.; Hospenthal, D.R.; Murray, C.K. Antimicrobial susceptibilities of geographically diverse clinical human isolates of Leptospira. Antimicrob. Agents Chemother. 2008, 52, 2750-2754. [CrossRef]

49. Gulland, F.M.D.; Koski, M.; Lowenstine, L.J.; Colagross, A.; Morgan, L.; Spraker, T. Leptospirosis in California sea lions (Zalophus californianus) stranded along the central California coast, 1981-1994. J. Wildl. Dis. 1996, 32, 572-580. [CrossRef]

50. Zuerner, R.L.; Cameron, C.E.; Raverty, S.; Robinson, J.; Colegrove, K.M.; Norman, S.A.; Lambourn, D.; Jeffries, S.; Alt, D.P.; Gulland, F. Geographical dissemination of Leptospira interrogans serovar Pomona during seasonal migration of California sea lions. Vet. Microbiol. 2009, 137, 105-110. [CrossRef] [PubMed]

51. Smith, A.W.; Brown, R.J.; Skilling, D.E.; DeLong, R.L. Leptospira pomona and reproductive failure in California sea lions. J. Am. Vet. Med. Assoc. 1974, 165, 996-998. [PubMed]

52. Smith, A.W.; Prato, C.M.; Gilmartin, W.G.; Brown, R.J.; Keyes, M.C. A Preliminary Report on Potentially Pathogenic Microbiological Agents Recently Isolated from Pinnipeds. J. Wildl. Dis. 1974, 10, 54-59. [CrossRef] [PubMed]

53. Piredda, I.; Ponti, M.N. Leptospirosis in Marine Mammals. In Leptospira Infection in Wild Animals; Fratini, F., Bertelloni, F., Cilia, G., Eds.; Nova Science Publisher: Hauppauge, NY, USA, 2020; pp. 9-52.

54. Prager, K.C.; Greig, D.J.; Alt, D.P.; Galloway, R.L.; Hornsby, R.L.; Palmer, L.J.; Soper, J.; Wu, Q.; Zuerner, R.L.; Gulland, F.M.D.; et al. Asymptomatic and chronic carriage of Leptospira interrogans serovar Pomona in California sea lions (Zalophus californianus). Vet. Microbiol. 2013, 164, 177-183. [CrossRef] [PubMed]

55. Norman, S.A.; DiGiacomo, R.F.; Gulland, F.M.D.; Meschke, J.S.; Lowry, M.S. Risk factors for an outbreak of leptospirosis in California sea lions (Zalophus californianus) in California, 2004. J. Wildl. Dis. 2008, 44, 837-844. [CrossRef] [PubMed]

56. Smith, A.W.; Brown, R.J.; Skilling, D.E.; Bray, H.L.; Keyes, M.C. Naturally-occurring leptospirosis in northern fur seals (Callorhinus ursinus). J. Wildl. Dis. 1977, 13, 144-148. [CrossRef]

57. Godínez, C.R.; De Romillo, B.Z.; Aurioles-Gamboa, D.; Verdugo-Rodríguez, A.; Rodríguez-Reyes, E.A.; De la Peña-Moctezuma, A. Antibodies against Leptospira interrogans in California sea lion pups from gulf of California. J. Wildl. Dis. 1999, 35, 108-111. [CrossRef]

58. Delaney, M.A.; Colegrove, K.M.; Spraker, T.R.; Zuerner, R.L.; Galloway, R.L.; Gulland, F.M.D. Isolation of Leptospira from a Phocid: Acute Renal Failure and Mortality from Leptospirosis in Rehabilitated Northern Elephant Seals (Mirounga angustirostris), California, USA. J. Wildl. Dis. 2014, 50, 621-627. [CrossRef]

59. Stamper, M.A.; Gulland, F.M.D.; Spraker, T. Leptospirosis in rehabilitated Pacific harbor seals from California. J. Wildl. Dis. 1998, 34, 407-410. [CrossRef]

60. Colegrove, K.M.; Lowenstine, L.J.; Gulland, F.M.D. Leptospirosis in northern elephant seals (Mirounga angustirostris) stranded along the California coast. J. Wildl. Dis. 2005, 41, 426-430. [CrossRef]

61. Kik, M.J.L.; Goris, M.G.; Bos, J.H.; Hartskeerl, R.A.; Dorrestein, G.M. An outbreak of leptospirosis in seals (Phoca vitulina) in captivity. Vet. Q. 2006, 28, 33-39. [CrossRef] [PubMed]

62. Stevens, E.; Lipscomb, T.P.; Gulland, F.M. An additional case of leptospirosis in a harbor seal. J. Wildl. Dis. 1999, 35, 150. [CrossRef] [PubMed] 
63. Greig, D.J.; Gulland, F.M.D.; Smith, W.A.; Conrad, P.A.; Field, C.L.; Fleetwood, M.; Harvey, J.T.; Ip, H.S.; Jang, S.; Packham, A.; et al. Surveillance for zoonotic and selected pathogens in harbor seals phoca vitulina from central California. Dis. Aquat. Organ. 2014, 111, 93-106. [CrossRef] [PubMed]

64. Hueffer, K.; Holcomb, D.; Ballweber, L.R.; Gende, S.M.; Blundell, G.; O’Hara, T.M. Serologic surveillance of pathogens in a declining harbor seal (Phoca vitulina) population in Glacier Bay National Park, Alaska, USA and a reference site. J. Wildl. Dis. 2011, 47, 984-988. [CrossRef]

65. Bauer, K.L.; Goertz, C.E.C.; Belovarac, J.A.; Walton, R.W.; Lawrence Dunn, J.; Tuomi, P. Infectious disease and toxicological monitoring of stranded pacific harbor seals (Phoca vitulina richardsi) in cook inlet as surrogates for monitoring endangered belugas (Delphinapterus leucas). J. Zoo Wildl. Med. 2016, 47, 770-780. [CrossRef]

66. Koizumi, N.; Uchida, M.; Makino, T.; Taguri, T.; Kuroki, T.; Muto, M.; Kato, Y.; Watanabe, H. Isolation and characterization of Leptospira spp. from raccoons in Japan. J. Vet. Med. Sci. 2009, 71, 425-429. [CrossRef]

67. Schnurrenberger, P.R.; Hanson, L.E.; Martin, R.J. Leptospirosis: Long-term surveillance on an Illinois farm. Am. J. Epidemiol. 1970, 92, 223-239. [CrossRef]

68. Mikaelian, I.; Higgins, R.; Lequient, M.; Major, M.; Lefebvre, F.; Martineau, D. Leptospirosis in raccoons in Quebec: 2 case reports and seroprevalence in a recreational area. Can. Vet. J. 1997, 38, 440-442.

69. Mitchell, M.A.; Hungerford, L.L.; Nixon, C.; Esker, T.; Sullivan, J.; Koerkenmeier, R.; Dubey, J.P. Serologic survey for selected infectious disease agents in raccoons from Illinois. J. Wildl. Dis. 1999, 35, 347-355. [CrossRef]

70. Warshawsky, B.; Lindsay, L.R.; Artsob, H. Leptospira infections in trappers from Ontario. Can. J. Infect. Dis. 2000, 11, 47-51. [CrossRef]

71. Scialfa, E.; Brihuega, B.; Venzano, A.; Morris, W.E.; Bolpe, J.; Schettino, M. First Isolation of Leptospira interrogans from Lycalopex griseus (South American Gray Fox) in Argentina Shows New MLVA Genotype. J. Wildl. Dis. 2013, 49, 168-172. [CrossRef] [PubMed]

72. Millán, J.; Candela, M.G.; López-Bao, J.V.; Pereira, M.; Jiménez, M.Á.; León-Vizcaíno, L. Leptospirosis in Wild and Domestic Carnivores in Natural Areas in Andalusia, Spain. Vector Borne Zoonotic Dis. 2009, 9, 549-554. [CrossRef] [PubMed]

73. Żmudzki, J.; Arent, Z.; Jabłoński, A.; Nowak, A.; Zebek, S.; Stolarek, A.; Bocian, Ł.; Brzana, A.; Pejsak, Z. Seroprevalence of 12 serovars of pathogenic Leptospira in red foxes (Vulpes vulpes) in Poland. Acta Vet. Scand. 2018, 60, 34. [CrossRef] [PubMed]

74. Slavica, A.; Dezdek, D.; Konjevic, D.; Cvetnic, Z.; Sindicic, M.; Stanin, D.; Habus, J.; Turk, N. Prevalence of Leptospiral Antibodies in the Red Fox (Vulpes vulpes) Population of Croatia. Vet. Med. 2011, 56, 209-213. [CrossRef]

75. Martino, P.E.; Montenegro, J.L.; Preziosi, J.A.; Venturini, C.; Bacigalupe, D.; Stanchi, N.O.; Bautista, E.L. Serological survey of selected pathogens of free-ranging foxes in southern Argentina, 1998-2001. OIE Rev. Sci. Tech. 2004, 23, 801-806. [CrossRef] [PubMed]

76. Zamora, J.; Riedemann, S. Wild animals as reservoirs of leptospirosis in Chile: Revision of studies in the country. Arch. Med. Vet. 1999, 31, 151-156. [CrossRef]

77. Da Silva, F.J.; dos Santos, C.E.P.; Silva, T.R.; Silva, G.C.P.; Loffler, S.G.; Brihuega, B.; Alarcon, M.F.F.; Curci, V.C.M.; Mathias, L.A.; Mathias, L.A. Search of leptospires and of antibodies against leptospires in animals and human beings in farms in Pantanal and Caatinga Brazilian biomes. Brazilian J. Vet. Res. Anim. Sci. 2015, 52, 234. [CrossRef]

78. Grune Loffler, S.; Rago, V.; Martínez, M.; Uhart, M.; Florin-Christensen, M.; Romero, G.; Brihuega, B. Isolation of a Seawater Tolerant Leptospira spp. from a Southern Right Whale (Eubalaena australis). PLoS ONE 2015, 10, e0144974. [CrossRef]

79. Piredda, I.; Palmas, B.; Noworol, M.; Tola, S.; Longheu, C.; Bertasio, C.; Scaltriti, E.; Denurra, D.; Cherchi, M.; Picardeau, M.; et al. Isolation of Leptospira interrogans from a Bottlenose Dolphin (Tursiops truncatus) in the Mediterranean Sea. J. Wildl. Dis. 2020. [CrossRef]

80. Smith, A.W.; Skilling, D.E.; Benirschke, K.; Albert, T.F.; Barlough, J.E. Serology and virology of the bowhead whale (Balaena mysticetus L.). J. Wildl. Dis. 1987, 23, 92-98. [CrossRef]

81. Mathews, P.D.; Da Silva, V.M.F.; Rosas, F.C.W.; D'Affonseca Neto, J.A.; Lazzarini, S.M.; Ribeiro, D.C.; Dubey, J.P.; Vasconcellos, S.A.; Gennari, S.M. Occurrence of antibodies to toxoplasma gondii and Lepstospira spp. in manatees (Trichechus inunguis) of the Brazilian Amazon. J. Zoo Wildl. Med. 2012, 43, 85-88. [CrossRef]

82. Sulzner, K.; Kreuder Johnson, C.; Bonde, R.K.; Auil Gomez, N.; Powell, J.; Nielsen, K.; Luttrell, M.P.; Osterhaus, A.D.M.E.; Aguirre, A.A. Health Assessment and Seroepidemiologic Survey of Potential Pathogens in Wild Antillean Manatees (Trichechus manatus manatus). PLoS ONE 2012, 7. [CrossRef] [PubMed]

83. Mathews Delgado, P.; Sanchez Perea, N.; Biffi Garcia, C.; García Davila, C.R. Detection of infection with Leptospira spp. in manatees (Trichechus inunguis) of the Peruvian Amazon. Lat. Am. J. Aquat. Mamm. 2015, 10, 58. [CrossRef]

84. Sánchez-Sarmiento, A.M.; Carvalho, V.L.; Meirelles, A.C.O.; Gravena, W.; Marigo, J.; Sacristán, C.; Costa-Silva, S.; Groch, K.R.; Dos Santos Silva, N.; Neto, J.S.F.; et al. Survey of Brucella spp. and Leptospira spp. Antibodies in cetaceans and manatees of the Amazon basin and Atlantic Ocean, Brazil. Dis. Aquat. Organ. 2018, 132, 1-11. [CrossRef] [PubMed]

85. Santa Rosa, C.A.; Sulzer, C.R.; Pestana de Castro, A.F. A new leptospiral serotype in the bataviae group, isolated in Sao Paulo, Brazil. Am. J. Vet. Res. 1972, 33, 1719-1721.

86. Santa Rosa, C.A.; Sulzer, C.R.; Giorgi, W.; da Silva, A.S.; Yanaguita, R.M.; Lobao, A.O. Leptospirosis in wildlife in Brazil: Isolation of a new serotype in the pyrogenes group. Am. J. Vet. Res. 1975, 36, 1363-1365.

87. Lins, Z.C.; Lopes, M.L. Isolation of Leptospira from wild forest animals in Amazonian Brazil. Trans. R. Soc. Trop. Med. Hyg. 1984, 78, 124-126. [CrossRef]

88. Liceras de Hidalgo, J.L.; Sulzer, K.R. Six new leptospiral serovars isolated from wild animals in Peru. J. Clin. Microbiol. 1984, 19, 944-945. [CrossRef] 
89. Liceras de Hidalgo, J. Leptospirosis in Tingo María, Huánuco Department, Peru. II. Study in wild animals. Bol. Of. Sanit. Panam. 1981, 91, 47-55.

90. Jorge, S.; Hartleben, C.P.; Seixas, F.K.; Coimbra, M.A.A.; Stark, C.B.; Larrondo, A.G.; Amaral, M.G.; Albano, A.P.N.; Minello, L.F.; Dellagostin, O.A.; et al. Leptospira borgpetersenii from free-living white-eared opossum (Didelphis albiventris): First isolation in Brazil. Acta Trop. 2012, 124, 147-151. [CrossRef]

91. Cordeiro, F.; Sulzer, C.; Ramos, A. Leptospira interrogans in several wildlife species in Southeast Brazil. Pesqui. Vet. Bras. 1981, 1, 19-29.

92. Brihuega, B.; Pavan, M.; Cairo, F.; Venzano, A.; Auteri, C.; Funes, D.; Romero, G.; Samartino, L. Pathogenic Leptospira in the kidney of Didelphys albiventris (weasel). Rev. Argent. Microbiol. 2007, 19, 19.

93. Reilly, J.R. The susceptibility of five species of wild animals to experimental infection with Leptospira grippotyphosa. J. Wildl. Dis. 1970, 6, 289-294. [CrossRef]

94. Schenk, J.A.P. Isolation of leptospira of the sero-group Hebdomadis of armadillos (Dasypus novemcinctus) captured in the State of Minas Gerais Brazil. Arq. Esc. Vet. UFMG 1976, 142, 468.

95. Dalazen, G.T.; Filho, A.F.d.S.; Sarmiento, A.M.S.; Fuentes-Castillo, D.; Gattamorta, M.A.; Kluyber, D.; Desbiez, A.L.J.; Heinemann, M.B.; Matushima, E.R. Survey of leptospira spp. and brucella abortus in free-ranging armadillos from Pantanal, Brazil. J. Wildl. Dis. 2020, 56, 409-413. [CrossRef]

96. da Silva, R.C.; Zetun, C.B.; Bosco, S.d.M.G.; Bagagli, E.; Rosa, P.S.; Langoni, H. Toxoplasma gondii and Leptospira spp. infection in free-ranging armadillos. Vet. Parasitol. 2008, 157, 291-293. [CrossRef]

97. Mori, M.; Bakinahe, R. Leptospirosis in Wild Rodents: Besides the rattus genus. In Leptospira Infection in Wild Animals; Fratini, F., Bertelloni, F., Cilia, G., Eds.; Nova Science Publisher: Hauppauge, NY, USA, 2020; pp. 79-124.

98. Fratini, F.; Turchi, B.; Ebani, V.V.; Bertelloni, F.; Galiero, A.; Cerri, D. The presence of Leptospira in coypus (Myocastor coypus) and rats (Rattus norvegicus) living in a protected wetland in Tuscany (Italy). Vet. Arh. 2015, 85, 407-414.

99. Shotts, E.B.; Andrews, C.L.; Harvey, T.S. Leptospirosis in selected wild mammals of the Florida panhandle and southwestern Georgia. J. Am. Vet. Med. Assoc. 1975, 167, 587-589.

100. Diesch, S.L.; Crawford, R.P.; McCulloch, W.F.; Top, F.H. Human Leptospirosis Acquired from Squirrels. New Engl. J. Med. 1967, 276, 838-842. [CrossRef]

101. Masuzawa, T.; Okamoto, Y.; Une, Y.; Takeuchi, T.; Tsukagoshi, K.; Koizumi, N.; Kawabata, H.; Ohta, S.; Yoshikawa, Y. Leptospirosis in squirrels imported from United States to Japan. Emerg. Infect. Dis. 2006, 12, 1153-1155. [CrossRef]

102. Tsai, H.J.; Huang, H.C.; Lin, C.M.; Lien, Y.Y.; Chou, C.H. Salmonellae and campylobacters in household and stray dogs in Northern Taiwan. Vet. Res. Commun. 2007, 31, 931-939. [CrossRef] [PubMed]

103. Gozzi, A.C.; Guichón, L.M.; Benitez, V.V.; Romero, G.N.; Auteri, C.; Brihuega, B. First isolation of Leptospira interrogans from the arboreal squirrel Callosciurus erythraeus introduced in Argentina. Wildl. Biol. 2013, 19, 483-489. [CrossRef]

104. Jorge, S.; Monte, L.G.; Coimbra, M.A.; Albano, A.P.; Hartwig, D.D.; Lucas, C.; Seixas, F.K.; Dellagostin, O.A.; Hartleben, C.P. Detection of Virulence Factors and Molecular Typing of Pathogenic Leptospira from Capybara (Hydrochaeris hydrochaeris). Curr. Microbiol. 2012, 65, 461-464. [CrossRef] [PubMed]

105. Moreno, L.Z.; Miraglia, F.; Marvulo, M.F.V.; Silva, J.C.R.; Paula, C.D.; Costa, B.L.P.; Morais, Z.M.; Ferreira, F.; Neto, J.S.F.; Dellagostin, O.A.; et al. Characterization of Leptospira santarosai Serogroup Grippotyphosa Serovar Bananal Isolated from Capybara (Hydrochaeris hydrochaeris) in Brazil. J. Wildl. Dis. 2016, 52, 688-693. [CrossRef] [PubMed]

106. Marvulo, M.F.V.; Silva, J.C.R.; Ferreira, P.M.; De Morais, Z.M.; Moreno, A.M.; Doto, D.S.; Paixão, R.; Baccaro, M.R.; Vasconcellos, S.A.; Neto, J.S.F. Experimental Leptospirosis in capybaras (Hydrochaeris hydrochaeris) infected with Leptospira interrogans serovar pomona. J. Zoo Wildl. Med. 2009, 40, 726-730. [CrossRef] [PubMed]

107. Cilia, G.; Bertelloni, F.; Coppola, F.; Turchi, B.; Biliotti, C.; Poli, A.; Parisi, F.; Felicioli, A.; Cerri, D.; Fratini, F. Isolation of Leptospira serovar Pomona from a crested porcupine (Hystrix cristata, L., 1758). Vet. Med. Sci. 2020. [CrossRef]

108. Mitchell, D.; Robertson, A.; Corner, A.H.; Boulanger, P. Some observations on the diagnosis and epidemiology of leptospirosis in swine. Can. J. Comp. Med. Vet. Sci. 1966, 30, 211-217.

109. Coppola, F.; Cilia, G.; Bertelloni, F.; Casini, L.; D'Addio, E.; Fratini, F.; Cerri, D.; Felicioli, A. Crested porcupine (Hystrix cristata L.): A new potential host for pathogenic Leptospira among semi-fossorial mammals. Comp. Immunol. Microbiol. Infect. Dis. 2020, 70, 101472. [CrossRef]

110. Siti-Nurdyana, A.; Bahaman, A.; Sharma, R.; Azlan, C.; Abdul Razak, M. Serological prevalence of leptospiral infection in captive Malayan porcupines (Hystrix brachyura). J. Vet. Malaysia 2016, 28, 1-3.

111. Fornazari, F.; Langoni, H.; Marson, P.M.; Nóbrega, D.B.; Teixeira, C.R. Leptospira reservoirs among wildlife in Brazil: Beyond rodents. Acta Trop. 2018, 178, 205-212. [CrossRef]

112. Lagadec, E.; Gomard, Y.; Le Minter, G.; Cordonin, C.; Cardinale, E.; Ramasindrazana, B.; Dietrich, M.; Goodman, S.M.; Tortosa, P.; Dellagi, K. Identification of Tenrec ecaudatus, a Wild Mammal Introduced to Mayotte Island, as a Reservoir of the Newly Identified Human Pathogenic Leptospira mayottensis. PLoS Negl. Trop. Dis. 2016, 10, e0004933. [CrossRef] [PubMed]

113. Desvars, A.; Naze, F.; Vourc'h, G.; Cardinale, E.; Picardeau, M.; Michault, A.; Bourhy, P. Similarities in Leptospira serogroup and species distribution in animals and humans in the Indian ocean island of Mayotte. Am. J. Trop. Med. Hyg. 2012, 87, 134-140. [CrossRef] [PubMed]

114. Desvars, A.; Cardinale, E.; Michault, A. Animal leptospirosis in small tropical areas. Epidemiol. Infect. 2011, 139, 167-188. [CrossRef] 
115. Matthias, M.A.; Mónica Díaz, M.; Campos, K.J.; Calderon, M.; Willig, M.R.; Pacheco, V.; Gotuzzo, E.; Gilman, R.H.; Vinetz, J.M. Diversity of Bat-Associated Leptospira in The Peruvian Amazon Inferred By Bayesian Phylogenetic Analysis Of 16s Ribosomal Dna Sequences. Am. J. Trop. Med. Hyg. 2005, 73, 964-974. [CrossRef] [PubMed]

116. Ferreira, A.S.; Ahmed, A.; Rocha, T.; Vieira, M.L.; Paiva-Cardoso, M.d.N.; Mesquita, J.R.; Linden, H.; Goris, M.; Thompson, G.; Hartskeerl, R.A.; et al. Genetic diversity of pathogenic leptospires from wild, domestic and captive host species in Portugal. Transbound. Emerg. Dis. 2019. [CrossRef]

117. Perolat, P.; Poingt, J.-P.; Vie, J.-C.; Jouaneau, C.; Baranton, G.; Gysin, J. Occurrence of Severe Leptospirosis in a Breeding Colony of Squirrel Monkeys. Am. J. Trop. Med. Hyg. 1992, 46, 538-545. [CrossRef]

118. Szonyi, B.; Agudelo-Flórez, P.; Ramírez, M.; Moreno, N.; Ko, A.I. An outbreak of severe leptospirosis in capuchin (Cebus) monkeys. Vet. J. 2011, 188, 237-239. [CrossRef]

119. Hyakutake, S.; de Biasi, P.; Santa Rosa, C.; Belluomini, H. Contribuiclo ao estudo epidemioldgico das leptospiroses em serpentes do Brasil. Rev. Inst. Med. Trop. Sao Paulo 1976, 18, 10-16.

120. Ferris, D.H.; Rhoades, H.E.; Hanson, L.E.; Galton, M.; Mansfiels, M.E. Research into the nidality of Leptospira ballum in campestral hosts including the hog-nosed snake (Heterodon platyrhinus). Cornell Vet. 1961, 51, 405-419.

121. Gravekamp, C.; Korver, H.; Montgomery, J.; Everard, C.O.; Carrington, D.; Ellis, W.A.; Terpstra, W.J. Leptospires isolated from toads and frogs on the Island of Barbados. Zentralbl. Bakteriol. 1991, 275, 403-411. [CrossRef]

122. Everard, C.O.R.; Carrington, D.; Korver, H.; Everard, J.D. Leptospires in the marine toad (Bufo marinus) on Barbados. J. Wildl. Dis. 1988, 24, 334-338. [CrossRef] [PubMed]

123. Alonso, M.L.; Cilia, G. Bat-Leptospira: A New Key. In Leptospira Infection in Wild Animals; Fratini, F., Bertelloni, F., Cilia, G., Eds.; Nova Science Publisher: Hauppauge, NY, USA, 2020; pp. 151-172.

124. Fennestad, K.L.; Borg-Petersen, C. Leptospirosis in Danish Wild Animals. J. Wildl. Dis. 1972, 8, 343-351. [CrossRef] [PubMed]

125. Bessa, T.Á.F.; Spichler, A.; Berardis Chapola, É.G.; Husch, A.C.; De Almeida, M.F.; Sodré, M.M.; Mouriz Savani, E.S.M.; Veiga Sacramento, D.R.; Vinetz, J.M. The contribution of bats to leptospirosis transmission in São Paulo City, Brazil. Am. J. Trop. Med. Hyg. 2010, 82, 315-317. [CrossRef] [PubMed]

126. Saraullo, V.; Grune, S.; Martinez, M.; Moreira, C.; Alonso, M.L.; Pastorino, F.; Auteri, C.; Martinez, G.; Brihuega, B. Detection of pathogenic Leptospira . in renal tissue from bats (Mammalia: Chiroptera) of Buenos Aires Province using duplex PCR. In Proceedings of the II Congreso Internacional de Zoonosis IX Congreso Argentino de Zoonosis, Buenos Aires, Argentina, 5-7 June 2018; p. 253.

127. Smythe, L.D.; Field, H.E.; Barnett, L.J.; Smith, C.S.; Dohnt, M.F.; Symonds, M.L.; Moore, M.R.; Rolfe, P.F. Leptospiral Antibodies in Flying Foxes in Australia. J. Wildl. Dis. 2002, 38, 182-186. [CrossRef] [PubMed]

128. Cox, T.E.; Smythe, L.D.; Leung, L.K.-P. Flying Foxes as Carriers of Pathogenic Leptospira species. J. Wildl. Dis. 2005, 41, 753-757. [CrossRef] [PubMed]

129. Zetun, C.; Hoffmann, J.; Silva, R.; Souza, L.; Langoni, H. Leptospira spp. and Toxoplasma gondii antibodies in vampire bats (Desmodus rotundus) in Botucatu region, SP, Brazil. J. Venom. Anim. Toxins Incl. Trop. Dis. 2009, 15, 546-552. [CrossRef]

130. Bunnell, J.E.; Hice, C.L.; Watts, D.M.; Montrueil, V.; Tesh, R.B.; Vinetz, J.M. Detection of pathogenic Leptospira spp. infections among mammals captured in the Peruvian Amazon basin region. Am. J. Trop. Med. Hyg. 2000, 63, 255-258. [CrossRef]

131. Ballados-González, G.G.; Sánchez-Montes, S.; Romero-Salas, D.; Colunga Salas, P.; Gutiérrez-Molina, R.; León-Paniagua, L.; Becker I.; Méndez-Ojeda, M.L.; Barrientos-Salcedo, C.; Serna-Lagunes, R.; et al. Detection of pathogenic Leptospira species associated with phyllostomid bats (Mammalia: Chiroptera) from Veracruz, Mexico. Transbound. Emerg. Dis. 2018, 65, 773-781. [CrossRef]

132. Mayer, F.Q.; Dos Reis, E.M.; Bezerra, A.V.A.; Cerva, C.; Rosa, J.; Cibulski, S.P.; Lima, F.E.S.; Pacheco, S.M.; Rodrigues, R.O. Pathogenic Leptospira spp. in bats: Molecular investigation in Southern Brazil. Comp. Immunol. Microbiol. Infect. Dis. 2017, 52, 14-18. [CrossRef]

133. Gomard, Y.; Dietrich, M.; Wieseke, N.; Ramasindrazana, B.; Lagadec, E.; Goodman, S.M.; Dellagi, K.; Tortosa, P. Malagasy bats shelter a considerable genetic diversity of pathogenic Leptospira suggesting notable host-specificity patterns. FEMS Microbiol. Ecol. 2016, 92. [CrossRef]

134. Ayral, F.C.; Bicout, D.J.; Pereira, H.; Artois, M.; Kodjo, A. Distribution of Leptospira serogroups in cattle herds and dogs in France. Am. J. Trop. Med. Hyg. 2014, 91, 756-759. [CrossRef] [PubMed]

135. Bertelloni, F.; Cilia, G. Leptospira Infection in Non-Human Primates. In Leptospira Infection in Wild Animals; Fratini, F., Bertelloni, F., Cilia, G., Eds.; Nova Science Publisher: Hauppauge, NY, USA, 2020; pp. 173-204.

136. Romero, P.M.; Astudillo, H.M.; Sánchez, V.J.; González, G.L.; Varela, A.N. Títulos de anticuerpos contra Leptospira sp., en primates del zoológico Matecaña, Pereira, Colombia. Rev. MVZ Córdoba 2012, 17, 3224-3230. [CrossRef]

137. Lilenbaum, W.; Monteiro, R.; Ristow, P.; Fraguas, S.; Cardoso, V.; Fedullo, L.P. Leptospirosis antibodies in mammals from Rio de Janeiro Zoo, Brazil. Res. Vet. Sci. 2002, 73, 319-321. [CrossRef]

138. Ullmann, L.S.; Neto, R.N.D.; Teixeira, R.H.F.; Nunes, A.V.; Silva, R.C.; Pereira-Richini, V.B.; Langoni, H. Epidemiology of leptospirosis at Sorocaba Zoo, São Paulo state, Southeastern Brazil. Pesqui. Vet. Bras. 2012, 32, 1174-1178. [CrossRef]

139. González Astudillo, V.; Hernández, D.W.; Stadlin, J.P.; Bernal, L.A.; Rodríguez, D.A.L.; Hernández, M.A. Comparative seroprevalence of Leptospira interrogans in Colombian mammals along a climatic gradient. J. Zoo Wildl. Med. 2012, 43, 768-775. [CrossRef]

140. Moreno-Beas, E.; Abalos, P.; Hidalgo-Hermoso, E. Seroprevalence of nine leptospira interrogans serovars in wild carnivores, ungulates, and primates from a zoo population in a metropolitan region of Chile. J. Zoo Wildl. Med. 2015, 46, 774-778. [CrossRef] 
141. De Souza Júnior, M.F.; Lobato, Z.I.P.; Lobato, F.C.F.; Moreira, É.C.; de Oliveira, R.R.; Leite, G.G.; Freitas, T.D.; de Assis, R.A. Presença de anticorpos da classe IgM de Leptospira interrogans em animais silvestres do Estado do Tocantins, 2002. Rev. Soc. Bras. Med. Trop. 2006, 39, 292-294. [CrossRef]

142. Baitchman, E.J.; Calle, P.P.; James, S.B.; Linn, M.J.; Raphael, B.L. Leptospirosis in Wied's marmosets (Callithrix kuhlii). J. Zoo Wildl. Med. 2006, 37, 182-185. [CrossRef]

143. Almeida, D.S.; Dos Santos, A.C.; da Silva, C.L.R.; Oriá, A.P.; Oliveira, A.V.D.; Libório, F.A.; Athanazio, D.A.; Pinna, M.H. Evidence of leptospiral exposure in neotropical primatesrescued from illegal trade and a Zoo in Bahia, Brazil. Pesqui. Vet. Bras. 2016, 36, 864-868. [CrossRef]

144. Pinna, M.H.; Martins, G.; Pinheiro, A.C.O.; Almeida, D.S.; Oriá, A.P.; Lilenbaum, W. Detection of anti-Leptospira antibodies in captive nonhuman primates from Salvador, Brazil. Am. J. Primatol. 2012, 74, 8-11. [CrossRef]

145. Ebani, V.V. Domestic reptiles as source of zoonotic bacteria: A mini review. Asian Pac. J. Trop. Med. 2017, 10, 723-728. [CrossRef] [PubMed]

146. Rodrigues, T.C.S.; Santos, A.L.Q.; Lima, A.M.C.; Gomes, D.O.; Brites, V.L.C. Anti-Leptospira spp. antibodies in Crotalus durissus collilineatus kept in captivity and its zoonotic relevance. Acta Trop. 2016, 158, 39-42. [CrossRef] [PubMed]

147. Stanchi, N.O.; Grisolia, C.S.; Martino, P.E.; Peluso, F. Presence of antileptospira antibodies in ophidia in Argentina. Rev. Argent. Microbiol. 1986, 18, 127-130. [PubMed] 